\title{
Strategic Communication in Public Participation
}

\author{
Saidathul Nizah Mat Tazin, Shira Haniza Yaakop \\ saidathul06@yahoo.com, shira_yaakop@yahoo.com
}

\begin{abstract}
This paper emphasises significantly on public relations strategic planning in public participation to gain organisational effectiveness. Grunig (1992) describes organisation's decision affects public and in turn the public affect the organisation's decision. This paper discusses the Situational theory of publics (Grunig, 1992) and highlights communication programmes for public participation in the development of slope area in Bukit Antarabangsa, Selangor. This paper suggests a framework of public relations strategic planning for public participation in MPAJ based on findings obtained from multiple methods of data collection.
\end{abstract}

Keywords: public relations, strategic planning, communication, public participation

eISSN 2514-7528 @ 2018. The Authors. Published for AMER ABRA cE-Bs by e-International Publishing House, Ltd., UK. This is an open-access article under the CC BY-NC-ND license (http:///creativecommons.org/licenses/bync-nd/4.0). Peer-review under responsibility of AMER (Association of Malaysian Environment-Behaviour Researchers), ABRA (Association of Behavioural Researchers on Asians) and CE-Bs (Centre for EnvironmentBehaviour Studies), Faculty of Architecture, Planning \& Surveying, Universiti Teknologi MARA, Malaysia.

DOI: https://doi.org/10.21834/jabs.v3i10.315 


\subsection{Introduction}

In the current changing environment managing public policy has become central to many organisations in reassuring the well-being of its stakeholder and maintaining a good reputation. As a result of this scenario, it is important for an organisation to discuss the planned policies with the affected publics for general understanding before decision making. Largely, this is about public participation. According to the International Association for Public Participation core values, public participation emphasizes on two-way communication and collaborative problem-solving to generate a constructive decision that benefits all parties.

The rising issues involving public on physical development of slope area in geo-hazard residential areas, in Malaysia, has earned the attention of many groups of public. The public insist for improvement in the mechanism of planning, construction, maintenance and legislation. The Ministry of Housing and Local Government highlights the National Physical Plan 2 (NPP-2) to build a sustainable environment for the well-being of the nation. NPP-2 underlines the national strategic spatial planning policies and measures of land in Malaysia 2020. The State Structure and Local Plans by state governments and federal agencies through the Action Area Plans and Programs are responsible for this role. NPP-2 emphasizes the importance of stakeholder while preparing and reviewing of NPP through public participation consultation programs including focus group discussions, dialogue sessions, and interactive opinion survey through electronic media, exhibitions, seminars, and workshops.

The purpose of this paper is to introduce public relations strategic approach in managing public participation in the development of slope area in the Municipal Council of Ampang Jaya (MPAJ).

\subsection{Literature Review}

The issue of public participation in the geo-hazards area in Malaysia has increased after the inundated landslides tragedy regularly hit the country. In most of the state and local agencies, the technical department manages public participation in town planning of the slope area development. Twenty years after the Highland Towers tragedy in Taman Hillview, Hulu Kelang, Selangor, the Malaysian authorities have considered seriously on policies and regulations in developing slope area in the state of Selangor. Municipal Council of Ampang Jaya (MPAJ), a local authority agency is responsible for executing town and country planning in slope development area. It is as prescribed in the Local Plans of MPAJ 2020 which was gazette on 20 May 2011 that involves the public. The development of slope area within class III (slopes 26 to 35 degrees) and IV (slopes more than 35 degrees) in Bukit Antarabangsa, Selangor, observes the major role of the Department of Urban Planning and the Slope Unit, Engineering Department of MPAJ in managing public participation. According to the Local Plans (Act 172), it is important to gain feedbacks from public participation before making any approval in the Local Plans.

Favourable feedback from public participation is highly expected, and thus, the concept of the mutual and beneficial relationship between the organisation and its public (Cutlip et.al, 
2006) is emphasised in the discipline of public relations. Scholars of communication stated that two-way symmetrical communication embraces the elements of ethical conduct, management understanding on public's views, dialogue and research (Grunig, 1992). Consequently, public relations strategic management creates an opportunity for the organisation to promote healthy understanding with its public.

Lerbinger (1997) claims natural disaster is one of the crisis types caused by environmental phenomena, which are uncontrollable, unpredictable that damage lives and properties of a country. Nevertheless, the impact of damages caused by disasters including of geo-hazard crisis reduces by looking at the crisis as a process (Jaques, 2009 \& Coombs \& Holladay, 2010). Proactive plans for emergency begins when there is no crisis and thus, conducting public participation programmes in slope development area is important to safeguard the image and reputation of the organisation. Cutlip (in Heath, 1997) argues that only through public relations expertise, we can hear public voices.

Strategic planning of public relations underlines the process of research, planning for objective, identifying publics, designing message, implementing communication within the time frame, budget, and evaluation. Organisation establishes public relations programs for each category of publics by verifying public's behaviour on information; use information, seek types of information, predict information and affected by information. Realising the importance of publics in strategic management, Grunig's situational theory of publics (Grunig, 1992) discusses three factors that move latent publics to become communicating active publics. Firstly, problem recognition represents the extent to which publics is aware of a situation and need the information to understand their present situation. Secondly, constrain recognition represents publics who is aware of their limitation in understanding a situation but realize with the information they can act on the situation. Finally, the level of involvement represents publics who is involved and affected by the situation and would communicate about the situation to others. Strategic communication encourages public participation and promotes better understanding.

\subsection{Methodology}

MPAJ was chosen as a case in point because of the frequent landslides that had happened in the jurisdiction area of the municipal council over the years. Furthermore, 17 out of 25 areas in the administration of MPAJ are critical landslides areas (Ainon Nisa et.al, 2012). MPAJ monitors 349 risky slopes per year to prevent hillside failure. At present, MPAJ informed there are 182 slopes belonged to the government, and the private entity owns 167 slopes.

This study employed snowball sampling to identify respondents who are responsible for managing public participation in the development of slope area in Bukit Antarabangsa (Merriam, 1998). The researcher conducted interviews with officers from MPAJ using interview instruments to understand their role in managing public participation in the development of slope area. Researcher obtained documents from MPAJ, newspaper clippings and National Physical Plan as secondary data to support the findings of this study. 


\subsection{Results and Discussions}

Public participation in slope development area in MPAJ happens at two continuums with an aim to inform the public of the slope development plan to avoid misunderstanding. It begins with notification and continues with on-going educational programs. The town and planning department of MPAJ claims upon deciding on the Local Plans, and there is a need to complete publicity in two stages. In the early publicity stage, a public hearing is arranged for explanation upon the approval of the Technical Committee of Environmental-Sensitive Areas comprising of Minerals \& GeoScience Department, Selangor Town \& Country Planning Department, Ikram GeoTechnical Services Sdn. Bhd., Public Works Department (JKR), Selangor Land Office and Department of Irrigation and Drainage chaired by the Director of Town Planning Department of Selangor. The technical committee informs the public on the objectives and purpose of the development besides other related matters. At this stage, public's feedback is important before outlining the draft for Local Plans. MPAJ said the slope development areas approval is based on three aspects including geological, technical and public safety. Among the members invited to the hearing, the session is the council members, land owners, residential associations, developers and technical expertise. However, media is not invited but is allowed to be present by the invitation of the residents.

During the second stage of the Local Plans publicity, it is important to publicise public inquiries in the least of two mainstream newspapers for not less than four (4) weeks or more than four (4) weeks (Seksyen 13(2), Act 172). MPAJ officer claims an extension period is allowed between two (2) to three (3) months for any objection before MPAJ conducts development session. The public who objects the development planned in the slope area is permitted to write to MPAJ. Six weeks before the meeting of the investigation committee and public hearing session, public are informed through a notice and called for a meeting with the council members, technical committees and town planning department to discuss further for clarifications and to avoid misunderstanding. Public view on the development of the respective slope area whichever is relevant is welcome by MPAJ assuming the public's familiarity with the slope surroundings. MPAJ ensures this session is permitted to build good relationships with the public.

The Engineering Department in MPAJ was set up in 2009 to manage technical stance of the slope before, during and after development is concern over structural stability and construction in the hillside development. The department has taken a step further to establish communication programs for public participation. The lists of programs produced are a website and a published booklet on guidelines on slope maintenance, URL link for public to report any signs of hillside failures, it supports the SlopeWatch group and organizes the seminar. One of the seminars held discusses on "Strategies to reduce the risks of landslides and geo-hazards in Bukit Antarabangsa, Ulu Klang, Selangor." MPAJ also gives an annual donation for the SlopeWatch community awareness program on a slope. These multiple efforts demonstrate MPAJ commitment in developing public participation on slope area development to prevent landslides tragedy from happening again.

Despite various efforts created for public participation on slope area development by MPAJ, there had been negative responses expressed by the non-governmental 
organisations calling on special engineering maintenance and judgment as slopes differs from one to another. According to the program director of SlopeWatch (previously known as CoBARA, Coalition of Bukit Antarabangsa Resident Association) Eriko Motoyama, currently the slope development guidelines posted to the public is general, and it qualifies only the minimum requirements for slope safety to avoid landslides from happening (The Star, $10^{\text {th }}$ December 2013). Public also has criticized MPAJ after numerous landslides tragedy in Bukit Antarabangsa (Star Online, 29th September 2013). The landowners who wish to develop the slope areas condemned the issues on levy imposed by the Selangor government. Disappointing with the state government plans the landowners drew the media attention and had implicitly included MPAJ in the news line (Metro, Star, $7^{\text {th }}$ October 2013). The issue on levy continues with elected representatives claim slope fee is unfair (Star Online, $9^{\text {th }}$ October 2013). For all these allegations, MPAJ expressed it has no control over the decision made by the state government on the issue of the levy that is currently being discussed at the state level. In the subject of slope development, in Bukit Antarabangsa MPAJ responses were technical advice for landowners and developer to be equally responsible for monitoring and maintaining slope in its area. MPAJ admitted the complexity in managing public participation despite the multiple efforts made to disseminate information before any development to create awareness to the public.

In the case of Bukit Antarabangsa, the resident association effort to establish a SlopeWatch group demonstrated a sense of community and community engagement by supporting public participation in slope development for safety environment. Bukit Antarabangsa property and landowners living in a selected elite area is expected to have a sense of high community belongingness that encourages sustainable living (Heng Zhang \& Shih-Hsien Lin, 2012). Note that this strategic public of MPAJ is attentive and well informed of their surroundings.

\section{Public relations strategic planning}

In this case study, the researcher proposed a public relations strategic plan to develop a reliable two-way communication programme in the issue of public participation in MPAJ. The issue of landslides in Bukit Antarabangsa has raised the anxiety from the majority of public with different interest, size, and structure which had scrutinized and reacted negatively on MPAJ responses in managing slope development in Bukit Antarabangsa. MPAJ is expected to conduct continuously environmental scanning, identifying and managing issues triggered by major public that has the potential to harm MPAJ's credibility in developing and maintaining slope development in Bukit Antarabangsa. Problem statements obtained from the public's common interests and collective views help MPAJ to determine the current situation affecting its strategic public.

Situation analysis examined from the interviews and newspaper clippings found that MPAJ underlined seven phases of slope development involving the different groups of public (refer to Table 1.0). Referring to the situational theory of publics (Grunig, 1992), the public involved in public participation for slope development in MPAJ may belong to any of these three categories of public; Firstly, public who were affected by the decisions and enforcement 
by MPAJ, query the credibility of MPAJ in developing slope area. Secondly, public who were affected by MPAJ decisions opted to be silent but continue to observe the situations and decides when the right time arrives to agree or disagree with MPAJ. Lastly, public who were unaffected by the development of slope area decided to respect the opinions of the majority public. These are the patterns of public behaviour managed by MPAJ in public participation for slope development. Segregating these groups of public according to issues is crucial as planning two-way communication program for each category of public generates favourable behavioural change towards MPAJ.

Table 1.0 Framework of public relations strategic planning for public participation in slope development, MPAJ

\begin{tabular}{|c|c|c|c|c|c|c|c|}
\hline \multirow{2}{*}{$\begin{array}{l}\text { PR Progranme } \\
\text { Planning }\end{array}$} & \multicolumn{7}{|c|}{ Slope Develocment Phases } \\
\hline & \multirow[t]{2}{*}{ Planning } & \multirow[t]{2}{*}{ Construction } & \multirow[t]{2}{*}{ Maintenance } & \multirow[t]{2}{*}{ Enforcement } & \multirow[t]{2}{*}{ Legislation } & \multirow{2}{*}{$\begin{array}{l}\text { Hillside } \\
\text { Failures }\end{array}$} & \multirow[t]{2}{*}{ Landside } \\
\hline $\begin{array}{l}\text { Strategic Public } \\
\text { Involvement }\end{array}$ & & & & & & & \\
\hline Land Ovmers & $x$ & $x$ & $x$ & $\mathrm{x}$ & $x$ & $x$ & $x$ \\
\hline $\begin{array}{l}\text { Resident } \\
\text { Association }\end{array}$ & $x$ & $\mathrm{x}$ & $\mathrm{x}$ & $x$ & $x$ & $x$ & $x$ \\
\hline Stafe Gout. & $x$ & $\mathrm{x}$ & $x$ & $x$ & $x$ & $\mathrm{x}$ & $x$ \\
\hline Developer & & $\mathrm{x}$ & $x$ & $x$ & $x$ & $x$ & $x$ \\
\hline Media & & & & & & $x$ & $x$ \\
\hline Activist & & & & & & $x$ & $x$ \\
\hline Local Authorities & & & & $\mathrm{x}$ & $x$ & $x$ & $x$ \\
\hline General Public & & & & & & $x$ & $x$ \\
\hline Cbjective & \multicolumn{5}{|c|}{ To inform, discuss and educate targeted public } & \multicolumn{2}{|c|}{$\begin{array}{l}\text { To inform, empathise } \\
\text { and build trust }\end{array}$} \\
\hline Communication & \multicolumn{5}{|c|}{$\begin{array}{l}\text { Publicity in media, Information sharing session, dialogue session, Safety Taks } \\
\text { and simulation, CSR programmes, etc. }\end{array}$} & \multicolumn{2}{|c|}{$\begin{array}{l}\text { Activate } \\
\text { communication }\end{array}$} \\
\hline Evaldation & \multicolumn{5}{|c|}{$\begin{array}{l}\text { Analyse feedback, estimate crowds, view complaints, view media coverage, } \\
\text { etc. }\end{array}$} & \multicolumn{2}{|c|}{$\begin{array}{l}\text { Analyse stakeholder } \\
\text { reactions post-crisis }\end{array}$} \\
\hline
\end{tabular}

Two-way Communication between MPAJ and its public

The public relations strategic plan highlights six elements of strategic planning; objective, public, communication strategy, tactics, message design, and evaluation (for this study, the budget is not included) that is applicable in MPAJ. Objectives are formed to inform and educate the publics on various phases of slope development to achieve understanding. The public is defined according to its role, participation and commitment in the slope development area. Messages to the strategic public are designed to describe MPAJ commitment in developing a sustainable environment for the society. Messages are tailored according to the level of understanding for each strategic public to prevent misunderstanding and underline the benefits gained for both parties. These messages would then be communicated tactically with an allocated time frame and approved the budget by the top level management. Hillside failures and landslides are situations in the slope development phases that require critical communication attention and organisational response. Lastly, evaluation is conducted to assess the effectiveness of the public participation program through behavioural changes 
among targeted publics. Table 1.0 describes the framework of public relations strategic planning in public participation in slope development, MPAJ

\subsection{Conclusion}

Town and Country Planning Act 1976 (Act 172) Part III on Development Plans in Section 9 of publicity in connexion with the preparation of draft structure plans (Town and Country Planning Act 1976 (Act 172) \& Order) states the essential for public participation in the development of Local Plans. MPAJ is expected to be attentive to public's opinion and demonstrates interest by conducting interactive activities ethically to make a better decision for better living.

Public relations strategic planning integrates public participation programmes in four states of slope development phases; pre-develop initiatives, composition (construction and protection), execution (enforcement and legal), and emergencies (hillside failures and landslides) with its multiple publics. Public relations value supports effective public participation that relates to empowerment, communication, and responsibility to understand issues, values and process (Azni \& Nuraisyah, 2013) thus, contributes to a sustainable environment and reputation building.

\section{Acknowledgement}

The authors would like to thank officers from the Municipal Council of Ampang Jaya (MPAJ) for providing information for this study.

\section{References}

Ainon Nisa Othman, Wan Mohd. Naim. W.M. \& Noraini, S. (2012). Proceedings from Procedia -Social and Behavioral Sciences 2012. Asia Pacific International Conference on Environment-Behaviour Studies. Elsevier B.V.

Azni Mohd Dian \& Nuraisyah Chua Abdullah. (2013). Proceedings from Procedia - Social and Behavioral Sciences 2013. AMER International Conference on Quality of Life. Elsevier B.V.

Coombs, W.T. \& Holladay, S.J. (Ed.) (2010). The handbook of crisis communication. West Sussex: Wiley-Blackwell

Cutlip S.M., Center A.H., \& Broom G.M. (2006). Effective public relations. (9th edition). Englewood Cliffs, NJ: Prentice Hall

Grunig, J.E. (Ed.). (1992), Excellence public relations and communication management. Mahwah, N.J: Lawrence Erlbaum Associates

Heath, R.L. (1997). Strategic issues management: Organisations and public policy challenges. Thousand Oaks: Sage publications

Heng Zhang \& Shih-Hsien Lin. (2012). Proceedings from Procedia - Social and Behavioral Sciences 2012: Asia Pacific International Conference on Environment-Behaviour Studies. Elsevier B.V. 
Lerbinger, O. (1997). Crisis Manager: Facing risk and responsibility. Mahwah, NJ: Lawrence Erlbaum Merriam. (1998). Qualitative research and case study: Applications in education. San Francisco: Josey-Bass

National Physical Plan 2. (2010). Federal Department of Town and Country Planning, Ministry of Housing and Local Government.

Rancangan Tempatan Majlis Perbandaran Ampang Jaya 2020: Strategi dan Cadangan Pembangunan. (2011). Prepared for the Subseksyen 12 (1) under the Town and Country Planning Act 1976. Prepared by Jabatan Perancangan Bandar dan Desa Semenanjung Malaysia, Majlis Perbandaran Ampang Jaya and Jabatan Perancangan Bandar dan Desa Negeri Selangor

Town and Country Planning Act 1976 (ACT 172) \& Order, as at 15 ${ }^{\text {th }}$ February 2013. Bandar Damansara Perdana: International Law Book Services

Choong Mek Zhin.( 2013, October 7). Unexpected fee. StarMetro. The Star

Lee Mei Li, Shalini Ravindran and Shalin Ho. (2013, December 10). Guidelines alone not enough, says NGO. The Star

Choong Mel Zhin. (2013, October 9). Elected representatives want planned slope fee scrapped. The Star Online. Retrieved from http://www.thestar.com.my/news/community /2013/10/09/In-a-tizzy-over-levy-Electedrepresentatives-want-planned-slope-fee-scrapped.aspxl

Residents take it upon themselves to monitor slopes. (2013, September 29). The Star Online. Retrieved from http://www.thestar.com.my/News/Nation/2013/09/29/Residents-take-it-upon-themselves-to-monitor-slopes.aspx/

IAP2 Core Values of Public participation. Retrieved October, $10 \quad 2013$ from http://iap2.affiniscape.com/associations/4748/files/CoreValues.pdfhttp://www.iap2.org 